\title{
Being-in-context through live projects in architectural education: Including situated knowledge in community engagement projects
}

\author{
Clint Abrahams ${ }^{1 \#}$, Hermie Delport ${ }^{2}$, Rudolf Perold ${ }^{3}$, Anna Marijke Weber ${ }^{4}$, and James Benedict \\ Brown $^{5}$ \\ ${ }^{1}$ University of Cape Town \\ 2 STADIO Higher Education \\ ${ }^{3}$ Cape Peninsula University of Technology \\ ${ }^{4}$ Rheinisch-Westfälische Technische Hochschule Aachen University \\ ${ }^{5}$ Umeå University \\ "Corresponding Author: clint.abrahams@uct.ac.za
}

(Submitted: 5 October 2020; Accepted: 21 September 2021)

\begin{abstract}
This paper explores the 'live project' as a pedagogical tool in architectural education in South Africa: one that allows educators and students, through pedagogies-in-context, to access and develop deeply situated knowledge(s) in the context of community engagement. We propose the concept of pedagogies-in-context as pedagogies in multiple overlapping contexts: the physical and social contexts of the higher-education institution, the intellectual, pedagogical, and political contexts of the curriculum, and the socio-economic contexts of educators, students, and communities. A live project allows for multiple ways of being-in-context - as students, educators, researchers, and community members. The paper employs an exploration of and critical reflection on one particular live project. Based on the critical reflection, we propose that in the South African context, live projects can be understood as enterprises to reconstitute situated knowledge(s), thereby empowering students and educators to rewrite their own experiences of learning and teaching by making meaningful connections with communities.
\end{abstract}

Keywords: architectural education, community engagement, live projects, situated knowledge

\section{Introduction: Pedagogies-in-context and pedagogies-out-of-context}

This paper explores the live project as a pedagogical tool in architectural education in South Africa: one that allows educators and students, through pedagogies-in-context, to access and develop deeply situated knowledge(s) in the context of community engagement. According to Anderson and Priest (2008),

A live project comprises the negotiation of a brief, timescale, budget and product between an educational organisation and an external collaborator for their mutual benefit. The 
project must be structured to ensure that students gain learning that is relevant to their educational development.

The paper employs a critical reflection on one particular live project and proposes that live projects can be understood in the South African context as enterprises to reconstitute situated knowledge(s), empowering students and educators to design their learning experiences through meaningful connections with communities. These connections include the situated knowledge of community members in live project processes and outcomes. The paper focuses on the architectural discipline, but by extension could be relevant to other design disciplines and as concept be adapted for any discipline.

The context of architectural pedagogy is the design studio as dedicated learning and teaching space. The dominant approach in the studio is problem-based methodology, manifested through 'a brief' as project assignment. Students respond by designing an architectural project. These projects are usually fictional but set within real-world contexts, often using existing physical sites. However, with the exception of community projects, work-integrated learning projects or design-build projects, the brief has no real client. It can be argued that by combining an imaginary building programme with a real context, the student and educator are responding to the brief in a fictional manner.

This fictionality places the project in opposition to the emphasis that the architectural curriculum places on an understanding of context. In any architectural project, context references - but is not limited to - the physical, environmental, cultural, and political. The studio is removed from these contexts that should inform the brief. South Africa is characterised by a diverse population and range of urban realities. In this heterogenic societal context, the disconnect is particularly problematic.

The live project provides an opportunity to expose students to the real contingencies of complex social, spatial, and political contexts. The normative studio however can still be a complementary space to the real-world live project, a safe space to which students can return and critically reflect on their learning. Students in live projects move 'between the studio and the street' (Sara, 2004: n.p), with one foot in the relative safe studio and the other in the unpredictable world beyond.

In this paper we propose the concept of pedagogies-in-context as pedagogies in multiple overlapping contexts: the physical and social contexts of the higher-education institution, the intellectual, pedagogical, and political contexts of the curriculum, and the socio-economic contexts of educators, students, and communities. The success of a live project is measured in real time through real responsibilities and experiences. Live projects challenge the primacy of the contextual frame of the higher education institution, the curriculum, the educator, and the student and allow for multiple ways of being-in-context.

Figure 1 depicts the normative project context of the architectural studio opposed to the context of the live project, and the various contexts that stakeholders bring. The normative project has few stakeholders (the students and the educator) and is strictly enclosed in the 
institutional context. The live project has numerous, varied stakeholders (the community, nonprofit organisations, professional practitioners, funders, etc.) and the context is more permeable -it is not bound to the extent of the project and some stakeholders are situated in context.

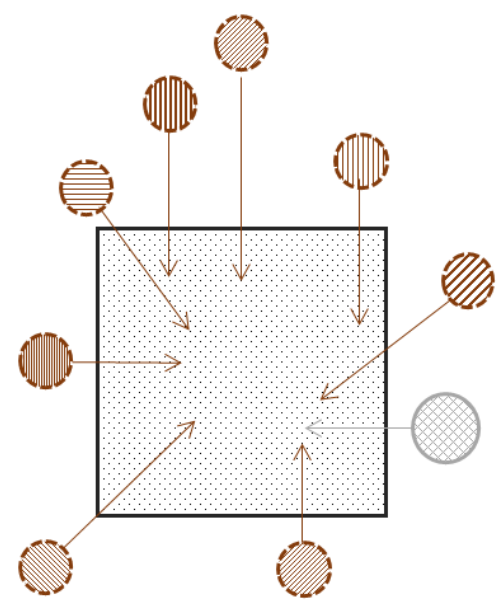

Normative project

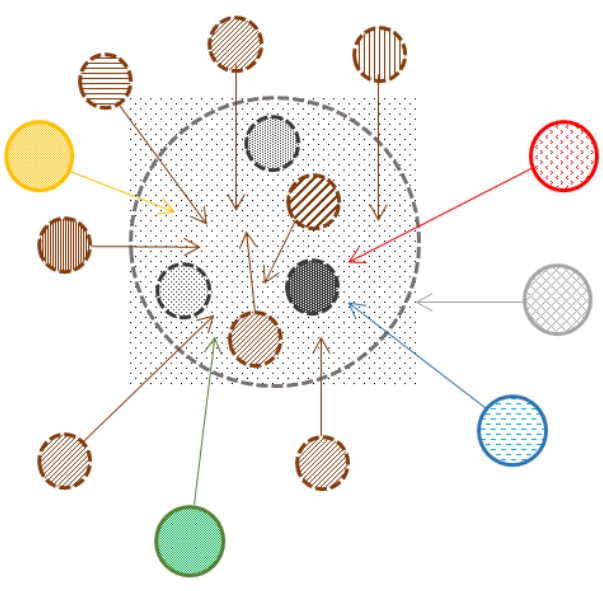

Live project

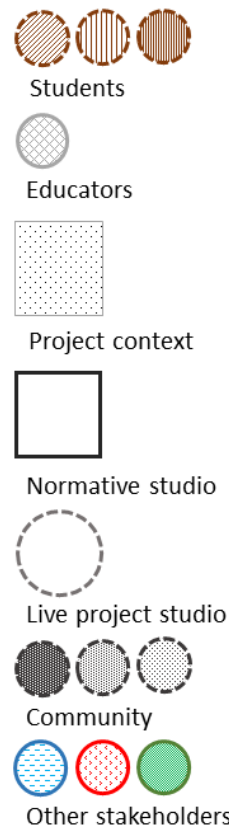

Figure 1: The normative project context of the architectural design studio as opposed to the context of the live project. Diagram by author.

We employ two discussions to elaborate on the context of our research - firstly addressing process, participants, and methodology, and secondly addressing live projects, community engagement, and situated knowledge. These provide a background to the subsequent problem statement. The live project narrative follows, written from the perspective of an educator situated in context. The narrative follows the story of the refurbishment of a shack structure in Macassar, Cape Town. The shack was redesigned and rebuilt to become a community meeting space. The narrative and the ensuing explorative discussion and critical reflection are structured according to a conceptual community engagement framework and reference the notion of being-incontext.

\section{Context: Process, participants, and methodology}

This paper originated with a presentation that discussed live projects as drivers for teaching and learning, community engagement, and research at the HELTASA 2019 conference ${ }^{1}$. It reviewed existing live project literature against a conceptual understanding of community engagement in

\footnotetext{
${ }^{1}$ HELTASA Pedagogies in Context conference, 27 - 29 November 2019, Rhodes University, Makhanda, South Africa
} 
South Africa (Bhagwan, 2017). It drew on our collective research and empirical experience in live projects and architectural education. The concept of situated knowledge was prominent, particularly the different knowledges brought to a live project by various stakeholders.

The conference presentation was informed by (but did not include) the narrative reflections on the live project. In this paper we employ collaborative writing practices to explore and critically reflect on this narrative. We consider how previously silenced perspectives - particularly the situated knowledges in communities - can be reintroduced to teaching in higher education. We aim to explore pedagogies-in-context that both valorise the different knowledges that exist to allow for multiple ways of being-in-context: as students, educators, researchers, and community members.

The geographical context of the live project is Macassar, a township close to Cape Town. The project was initiated by co-author Clint Abrahams, affiliated to the University of Cape Town and the situated educator. Clint is also the founder of Studiolight, a community development organisation whose participative practices aim to critically engage apartheid legacies by retelling the stories of less fortunate communities with the aim of generating spatial types in contexts with limited civic-institutional infrastructure. This live project forms part of an ongoing project that commenced in 2016.

The other co-authors are Hermie Delport (STADIO) and Rudolf Perold (Cape Peninsula University of Technology_CPUT) respectively. They coordinated the Design-Build Research Studio at CPUT between 2011 and 2018 and have experience of live projects in around Cape Town. Anna Marijke Weber of the Rheinisch-Westfälische Technische Hochschule Aachen University in Germany has been involved in regional live projects in Germany, embedded in a research context of migrant-initiated architecture. Her contribution focused on spatial analysis through drawings, developing a method of integrating community members' experience and knowledge. James Benedict Brown of Umeå University in Sweden contributes his research- and practice-based insights as a pedagogy-in-context. Through the inclusion of North-South perspectives we aim to encourage collaborative, transnational live projects as well as collaborative research writing practices.

Figure 2 illustrates the context of the co-authors. Clint Abrahams is the situated educator. $\mathrm{He}$ is not only the originator of the live project but is originally from the Macassar community. The other educators had various levels of involvement, as indicated by the grey arrows. 


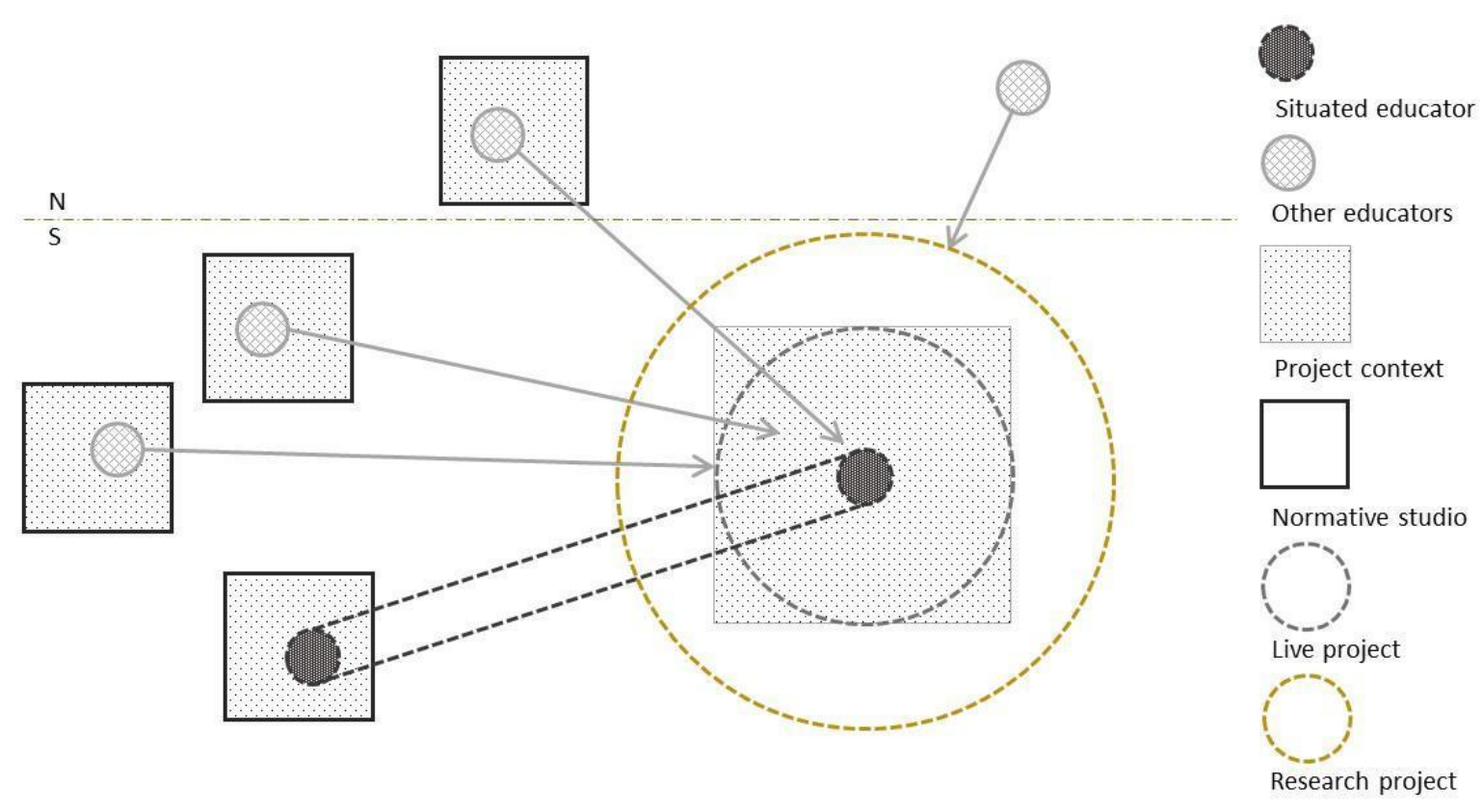

Figure 2: The context of the educators and co-authors. Diagram by author.

The situated educator's narrative reflections on the Macassar project became the starting point for our exploration. He adopted a very specific position as expert citizen (cf. Ogbu, 2013). In his words:

As an architect and educator raised in a less fortunate community, I recognise the importance of situated knowledge and the contribution to livelihoods in contexts designed to oppress. I am acutely aware of the dangers that assimilation in my profession and its traditional teaching methods holds for advocating the legitimacy of situated knowledge. I want to understand how this knowledge can critically engage with traditional architectural pedagogy and be reinterpreted to towards alternative pedagogies to produce future locally minded architects who can valorise situated knowledge.

Architect Liz Ogbu's description of the expert citizen and the citizen expert summarises why I do what I do, where I do what I do, and with whom I do what I do. She describes an expert citizen as someone who has been trained in some kind of expertise and a citizen expert as an individual who is armed with experience of living or working in a specific community. This pairing of the two terms views the expert as a person who has assumptions and ideals and aspirations like any other citizen. In turn, the citizen expert is viewed as a person with intrinsic knowledge that the expert is not necessarily privy to (Ogbu, 2013). It values both objective and subjective points of view when attempting to alter concrete realities (Freire, 1972).

Our exploration was developed through collaborative writing, drawing on collaborative 
autoethnography. Chang, et al. (2016: 17) define collaborative autoethnography as 'a qualitative research method that is simultaneously collaborative, autobiographical and ethnographic'. In his reflections, the situated educator employed two components of autoethnography: autobiographical data and a 'cultural interpretation of the connectivity between the self and others' (Chang, et al., 2016: 18). In our explorative method we built on the process in Macassar, which employed narrative strategies to access situated knowledges. Devos, et al. (2018) point to the value of embedding narrative modes within a participatory approach, where the 'story becomes an object of study' (Mitchell and Ugudo, 2003: 3).

The project narrative of Macassar is structured according to four themes describing a conceptual understanding of community engagement in South Africa: context, process, mutual beneficial relationships, and knowledge production (Bhagwan, 2017). Employing the project narrative as primary data set enabled the adoption what we refer to as a pedagogy-in-context through being-in-context. We employed collaborative discussions to interpret, reflect and prompt further search of the self by the situated educator. Structured synchronous online discussions were combined with asynchronous writing sessions in a collaborative online document. Sections of the paper were swapped between individuals for reflection and further elaboration. Collaborative writing methodologies are relevant as collaborative and participatory methodologies are accepted pedagogical approaches in live projects. The process of writing this paper allowed for collaborative reflexivity by combining collective experiences into a tangible entity.

\section{Context: Live projects, community engagement and situated knowledge Live projects}

Live projects in architectural education are pedagogical tools that take students out of the studio and challenge the normative studio-based architectural pedagogy. Live projects are demanding, resource-dependent endeavours, requiring preparation in terms of community consultation, health and safety and budget (Sheffield School of Architecture, 2013). The complexities of live projects are well documented (Sara, 2004; Brown, 2012; 2014; Anderson and Priest, 2014; Delport and Perold, 2016).

Live projects allow students with different knowledges and skills to contribute in ways not possible in the normative studio. Students have the opportunity to employ more social or technical skills. By involving real clients, live projects also address 'professional practice-ready skills and capabilities' (Harriss, 2014: 11), something that is not always possible in the normative studio. Harriss (ibid.) identifies these skills as 'collaborative interaction within and between interdisciplinary teams ... participatory engagement with clients and civic concerns and ... the capability to manage emergent ambiguities in risk exposure and decision-making'.

Despite these merits, live projects are subject to critique, in particular where non-local institutions undertake local projects. Preconceived ideas, a focus on learning, complex logistics, and the excitement of creating an intervention often result in community stakeholders and their situated knowledge not being incorporated. To reflect on this critique, the next section focuses 
on community engagement in the context of South Africa.

\section{Community engagement}

A Department of Education White Paper (DOE, 1997) positioned community engagement as equal to teaching, learning and research in South African higher education. In the South African context, 'community' predominantly refers to 'disadvantaged, materially poor residents of underserviced urban, peri-urban, or rural areas' (Bender, 2008: 86). We value this definition by Netshandama and Mahlomaholo (2010: 10):

Community engagement is that context, that space, a process and an outcome in the development of knowledge, one that seeks to challenge and change the existing notions of what and how knowledge is.

Critical engagement with practices and discourses (Netshandama and Mahlomaholo, 2010; Bhagwan, 2017) of community engagement (e.g. the type of live projects referenced here) requires conceptual, theoretical, and lived understandings of and reflections on the sociopolitical and ethical aspects.

We view live projects simultaneously as pedagogy, practice and (developing) conceptual framework. Higher-education in South Africa has proposed numerous conceptual frameworks. Bender (2008: 87) presents three models, the silo model, the intersecting model, and the infusion model, defined by the roles of the university and their relationships. O'Brien presents a framework of four discourses: scholarly, benevolent, democratic, and professional engagement, and employs five elements to define these discourses: 'context, identity, development, curriculum (and) power' (2012: 209).

Bhagwan (2017) defines four themes: context, process, mutually beneficial relationships, and knowledge production. Bhagwan's 2017 study engaged with literature and community engagement practitioners at South African public universities in an attempt to 'deconstruct ... (the) meaning through the activities and relationships that underpin contemporary community engagement in South Africa' (2017: 173). Bhagwan's research serves as a touchstone in this paper, and the project narrative and discussion are structured according to her four themes. The themes are introduced below and are diagrammatically captured in Figure 3.

\section{Context}

According to Bhagwan (2017), community engagement is a contextual activity characterised by the community and the higher-education institution. The community context refers to a specific geographic area or community of interest - often identified by disadvantage or social isolation while the latter is perceived to be an elite knowledge institution. These two contexts are different worlds with often contrasting realities. The higher-education institution is perceived as an 'ivory tower, literally "above" and "over" the surrounding communities' (Fourie, 2003: 33). Bender (2008: 85) points to institutional culture where the physical, philosophical, and epistemological contexts 
are often exclusionary.

\section{Process}

Bhagwan (2017) posits that community engagement requires academics to connect with communities in ways that foster change. Educators and students must strive for mutuality and reciprocity. Community engagement should allow the opportunity for the 'co-owning (of) the processes' (Netshandama and Mahlomaholo, 2010: 12). Bender is quite clear on the importance of reframing processes, stating that 'in order to build the collaborative relationships on which a complex activity such as community planning depends, the university system has to understand fully the dynamics of the communities with which it seeks to work, and be prepared to adapt and develop structures and processes to make them accessible and relevant to these' (2008: 86).

\section{Mutually beneficial relationships}

Such relationships, Bhagwan says (2017), are based on partnerships and reciprocity, and the codesigning of solutions. Community engagement involves two-way, mutually beneficial relationships underpinned by the strength, resilience, and situated knowledge of communities. Netshandama and Mahlomaholo (2010: 9) summarise this concept, stating that 'each party should listen to the other side(s) in order to understand, find meaning and find agreement. Bender refers to partnerships as the 'currency of engagement' (2008: 91), stating that only through collaboration a reciprocal relationship can be created.

\section{Knowledge production}

Bhagwan (2017) explains the paradigmatic shift from knowledge transfer to the co-creation of knowledge and the distilling of indigenous knowledge by involving community members. The co-production of knowledge draws on the practical, tacit, and experiential knowledge of community members, counterbalancing traditional academic knowledge through engaged knowledge generation. Netshandama and Mahlomaholo stress the importance of the status and power situated in knowledge, that certain knowledges can and have been marginalised, that knowledge is not 'neutral, objective, absolute or value free' (2014: 6), and that 'the processes of knowledge development cannot be underestimated' (ibid., 2014: 1).

The purpose of community engagement is understood as the partnership of a highereducation institution and its knowledges and resources with that of the public and private sectors in order to enrich scholarship, research, and creative activity; to enhance the curriculum, teaching and learning; to prepare educated and engaged citizens; to strengthen democratic values and civic responsibility; to address critical societal issues and to contribute to the public good (Kliewer, cited in Bhagwan, 2017: 174-5). This partnership necessitates a shift of focus from expert knowledge - which often impedes constructive community engagement - to the situated knowledge that exists in the context and the community. 


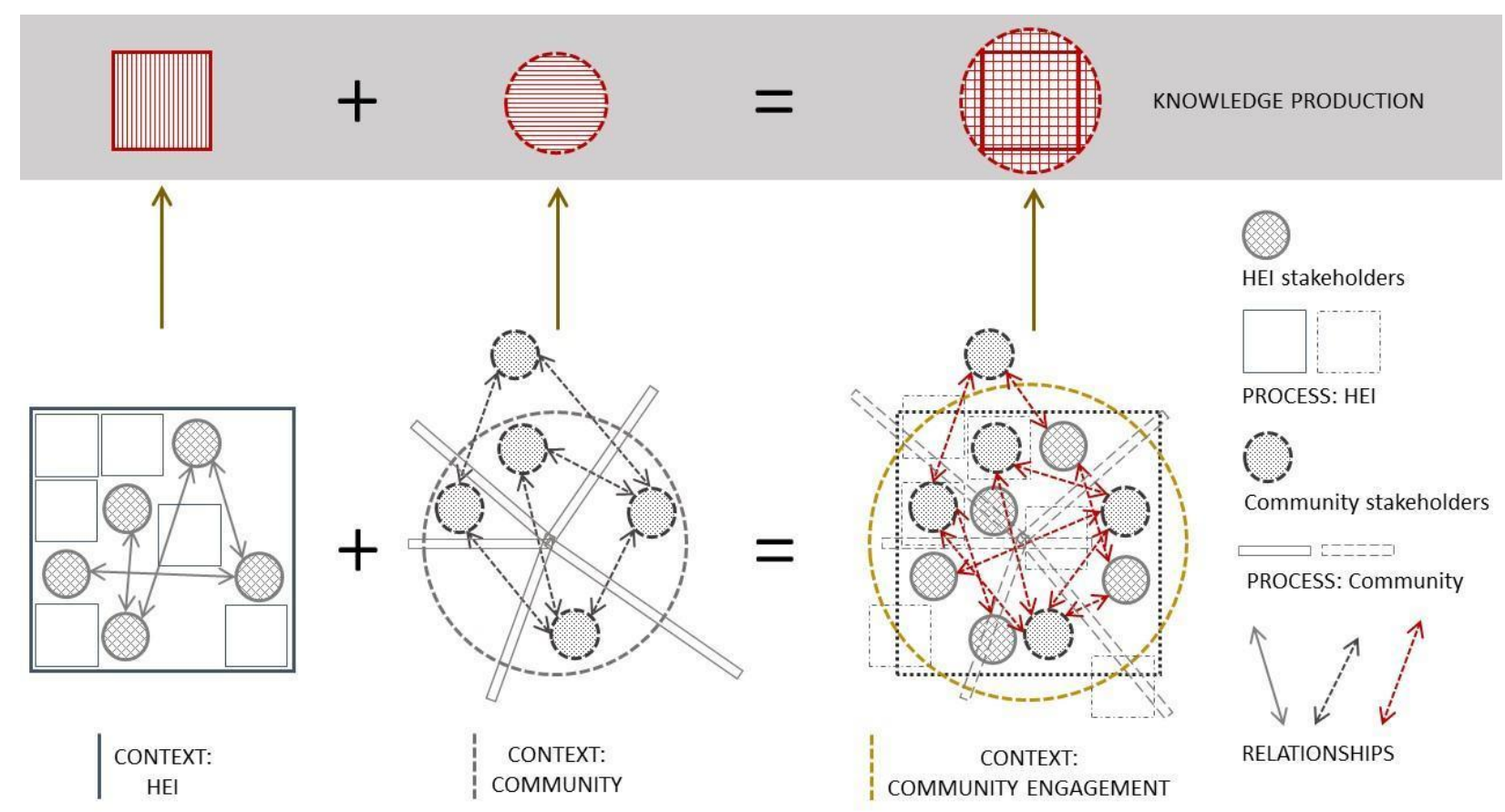

Figure 3: Context, process, relationships, and knowledge production. Diagram by author.

\section{Situated knowledge}

'Situated pedagogy encompasses the idea of contextualisation of learning and emphasises the need for curricula with real-world relevance. It expands work-related learning opportunities for students, and supports students in identifying and addressing "big issues" in industry, government, and society' (Witthaus, et al., 2019: 4).

Architectural education should pay attention to the 'social, cultural and experience differential' between different participants in the learning process (Brown, et al., 2012: n.p.). Situated pedagogy, as described above by Witthaus, et al. (2019: 4), is inherent in live projects. When students work with, for, and alongside community members, they have to negotiate between two value systems: the academic, by which their work will be assessed and the nonacademic, by which the community members' brief will be satisfied (ibid.).

However, it is difficult to engage with situated knowledge in an unfamiliar context, as it is tempting to co-opt such knowledge and to reproduce it in a more familiar top-down logic (Lau and Seedat, 2015: 372). Doing so negates the 'multifaceted, multilayered, dynamic plurality of communities by virtue of the intersecting social, economic, political and religious worlds' (Crossman and Devisch, 2002: 105). Instead, we must 'foreground "local conditions and local knowledge" and generate context specific, situated, rich, "thick description" and layered accounts of voices representing the community' (Pain cited inin Lau and Seedat, 2015: 373). Being-incontext together with all live project stakeholders makes it less likely that the situated knowledge in the context will be negated in favour of more familiar, abstract knowledge.

Many live projects are located in the everyday city. In contrast to self-conscious higharchitecture (Hill, 2005: 47) addressed by normative studios, spatial production in the everyday 
city is exposed to different forces: laypeople's spatial practices, little money, constant transformation, matter-of-factualness, less form, and more performance. To intervene architecturally in the everyday city requires making situated knowledge accessible through tools of analysis and representation. The emphasis of a normative design-studio project is often placed on the end product; a live project necessarily emphasises social processes. Storytelling, being characterised by process and relationality, allows situated knowledge to be explored collaboratively, without the 'urge to impose order and finality on that which emerges'. Such mutual learning experiences have the potential to produce knowledge networks - led and initiated by community members - that lead to future research (Lau and Seedat, 2015: 381).

In concluding this section on the context of our exploration, we have positioned ourselves in relation to the intersection of live projects, community engagement, and situated knowledge (Figure 4) to explore our own multiple ways of being-in-context.
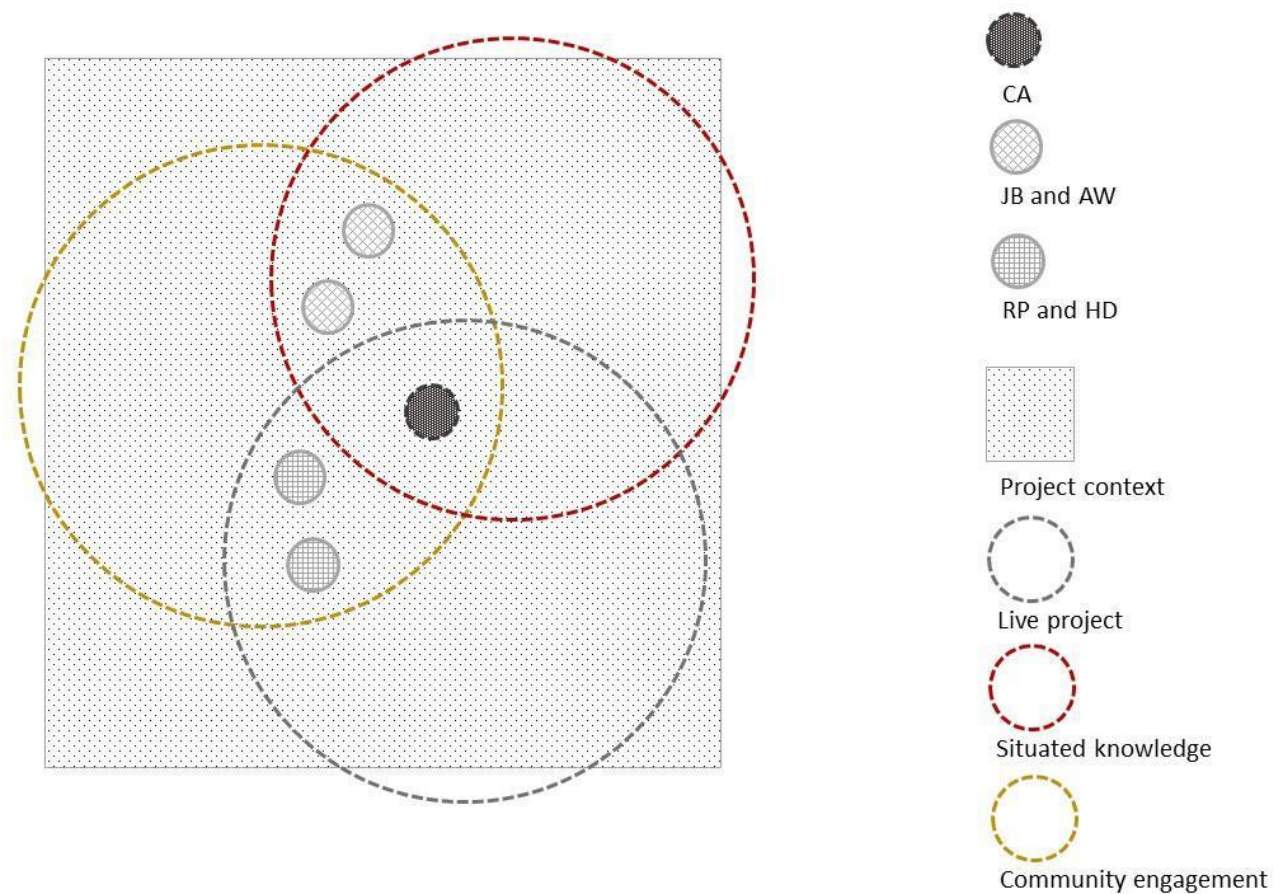

Figure 4: Mapping of the co-authors' respective experience and interest against the intersection of live projects, community engagement and situated knowledge. Diagram by author.

\section{Problem statement}

In South Africa, live projects are predominantly understood as a form of community engagement. For educators this involves addressing the enduring spatial legacy of apartheid-era policies. The apartheid regime's goals of race-based segregation and disempowerment are still evident in townships such as Macassar, and the associated negative spatial characteristics are still a part of everyday life. The existing urban fabric sustains and reproduces injustices. Communities have to find a way of addressing this. Architectural lay people become experts in transforming existing structures to make these conducive to contemporary community life. In live projects, this 
everyday expertise can complement the formal expertise of educators and students. It is important to explore how live projects can be framed so that situated pedagogies are of mutual benefit to all. Bhagwan (2017: 179) emphasises the voice of the community. We believe that the links between live projects, community engagement, and situated knowledge are not sufficiently theorised in the context of live projects.

There are shortcomings in many live projects, particularly in what we refer to as helicopter projects, in which students fly-in-fly-out with no sustained engagement. This is a risk affecting transnational live projects that connect the global North with communities and contexts in the global South. Students from the North raise funds and design a building that they will construct. Such remotely planned projects increase the risk that the higher education institution does not listen to the community, diminishing the possibility to fully contribute to long-term development. A major exhibition held in the Architecture Museum at the Technical University Munich in 2020 presented a collection of transnational live projects, some of which qualify as helicopter projects (Architekturmuseum der TUM, 2020). The press took up the discussion through straight-forward, pertinent questions:

How do you make sure that the projects do not develop in neocolonial structures? Where students are called "boss" just because they are white? And there is hardly any critique, because the buildings are a gift? (Weissmüller, 2020)

We frame our problematisation of live projects as a confrontation between pedagogy-outof-context and pedagogy-in-context. We choose to explore live projects as pedagogies-incontext, specifically as pedagogies in multiple overlapping contexts, a decision that demands stakeholders to inquire and to declare precisely which context and whose context they engage in as a way of being-in-context. By more closely interrogating the context of a live project, stakeholders ask not only where the project is located, but why it will be located there. Such interrogation raises important questions: Are live project participants going there to solve a problem for a community? Is the voice of the community taken into account? Is the context of the educator taken into account? Who leads the project? While the educator becomes an intermediary, what qualifies this individual to represent the interests of the community? From what context does this person come, and what do they bring with them from their own contexts? In the project narrative and discussion that follows, we hope to address some of these questions.

\section{Project narrative by the situated educator}

The community of Macassar has developed various spatial coping strategies. With these strategies, the community has successfully managed to transform the urban to address their needs, to the extent that it is becoming a vibrant urban area - strongly in contrast with its once intended planning goals. In this context, formal perfection or canonised beauty are sometimes secondary. The performance of spatial structures and situations has a high quality of its own. There is no question that governance, which cleverly transfers existing, non-formal phenomena 
into planning, can provide a supportive impulse. The cultural value lies in the way in which the community has carried out the spatial transformation of apartheid-built legacies. Figure 5 shows a model of a section of Macassar where building practices are reshaping the neighbourhood. Macassar is more than 'less fortunate', and can be described as a structurally disadvantaged community, where the government has failed to support adequate development. To intervene here has a political aspect, as it criticises current governance by making political shortcomings evident.

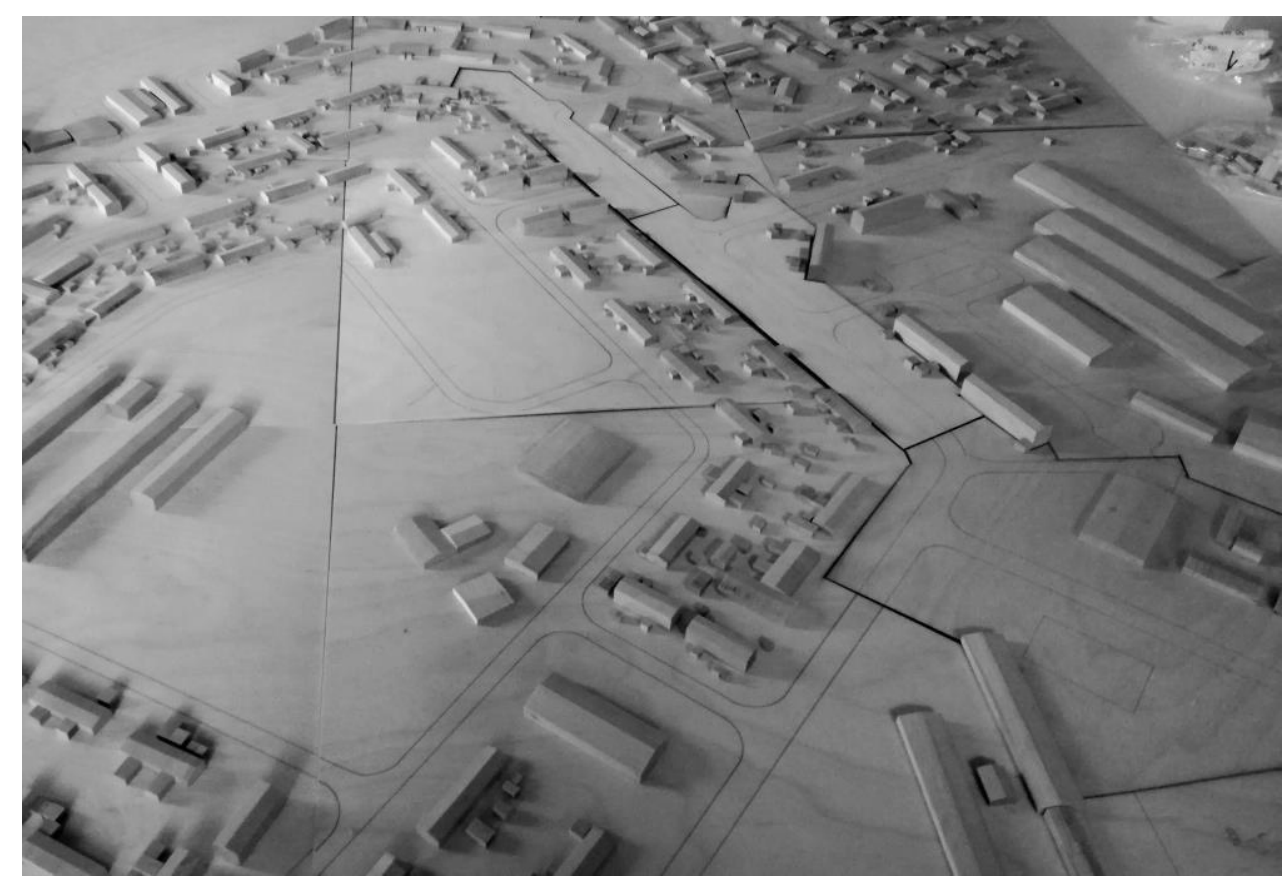

Figure 5: Model of Ring Avenue, Macassar, made by students. Photograph by author.

In July and September of 2019, thirty students and educators joined representatives of the community of Macassar to design and build a common storytelling space. The township set the scene to build onto an ongoing community-engagement project facilitated by a non-profit organisation that sought to uncover sustainable forms of community-institutional exchange.

\section{Context}

How group participants perceive certain contexts and each other will have an impact on how their relationships define a project's objectives (Moore cited in Bhagwan, 2017: 176). In these relationships, particularly when working in less fortunate communities, educators are often seen as upper class by communities, while communities are identified as a less-privileged group. It is the bringing together of these opposing perspectives and contexts that is at the heart of community engagement (Bernardo, et al., 2014: 117).

In 2016, together with a group of youth, my students and I self-organised to build community resilience through storytelling. Workshops with our community developed into a 
street photography project and a participatory exhibition where community members exchanged stories in response to the photographs taken and exhibited. This exhibition gave rise to the need for a space where we could continue the harnessing of stories. In 2019, the refurbishment of an old shack presented an opportunity to accommodate community storytelling and intersect the situated knowledge with the disciplinary knowledge of the students. This process provided a space to reinterpret traditional architecture knowledge through and within a live project. The community was represented by a group of local storytellers who shared their experiences of life in Macassar by reflecting on their self-made spaces. Together with writer and poet Diana Ferris, a series of sessions was held to solicit insight from the participating storytellers, as seen in Figure 6.

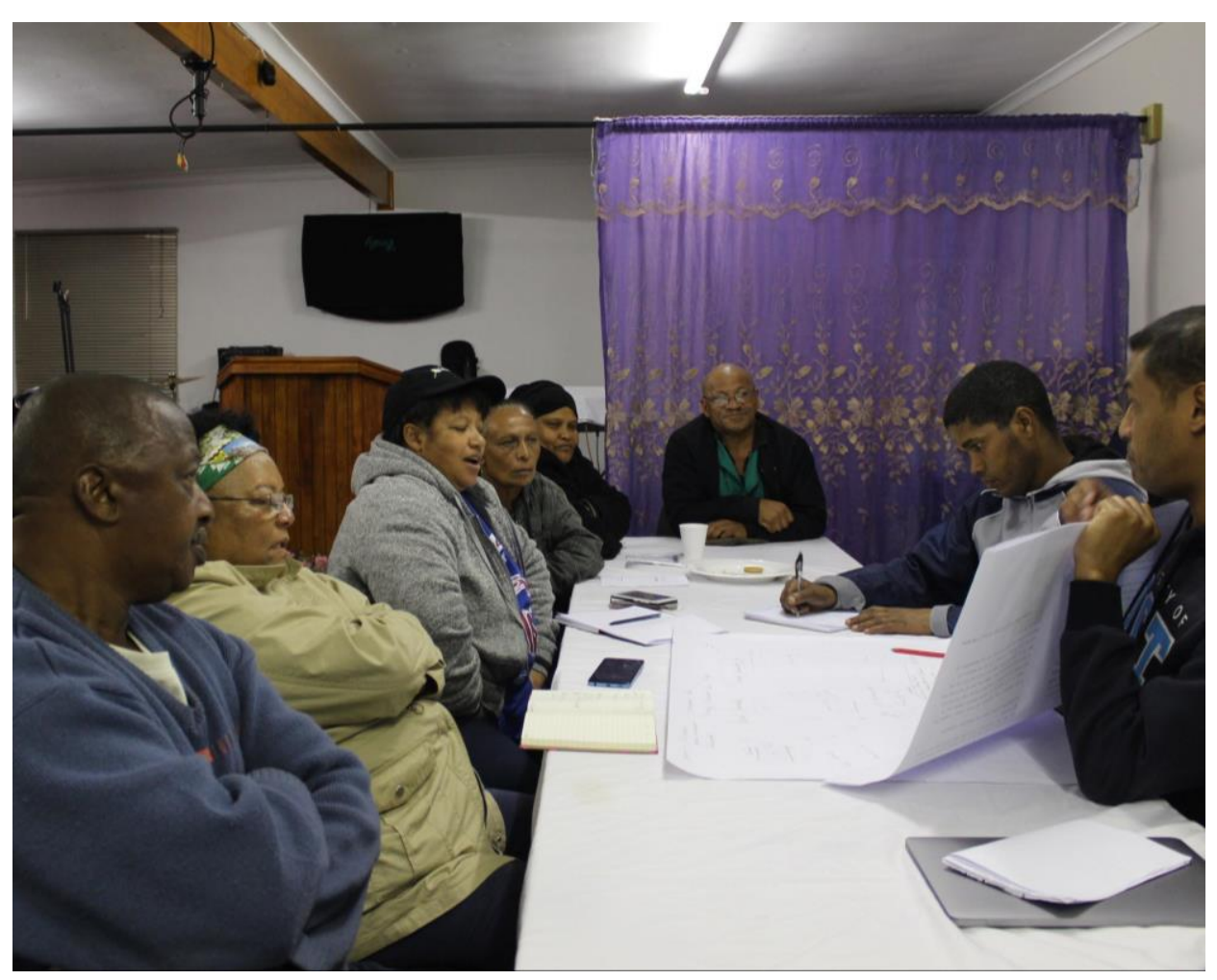

Figure 6: Poet and writer Diana Ferris and the situated academic working with local storytellers. Photograph by author.

As an emergent educator, my position at the School of Architecture, Planning and Geomatics at UCT allowed me to further explore a previous relationship with colleagues of the RWTH Aachen University and PBSA Dusseldorf University. Our three institutions share a research interest on how live projects can produce positive social impact. By hosting a summer/winter school (funded by DAAD), we were brought together students from Germany and South Africa. To diversify the participation, we invited educators and students from CPUT, as well as an educator from STADIO. The winter school comprised a series of field trips, lectures, workshops, and exhibitions. This work informed the design of a roof structure for the old shack as part of the 
first phase. The field trips, lectures, workshops and exhibitions took place in self-made spaces in the community (Figure 7) and allowed these two contexts - community and higher education institution - to come together. In the second phase, during September 2019, the completion of the roof design as a design-build live project concluded the winter school.

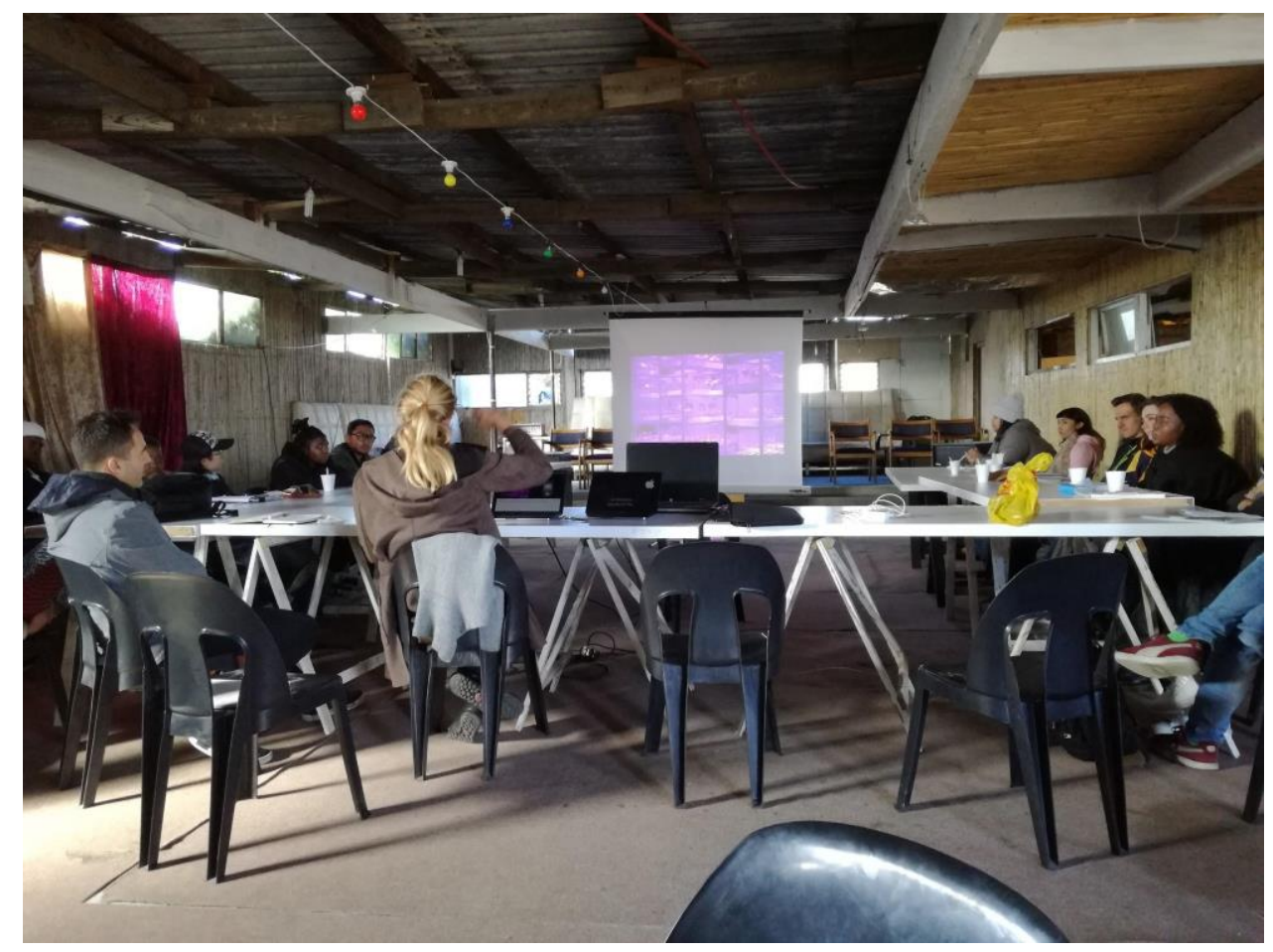

Figure 7: Lectures and workshop conducted in self-made structure. Photograph by author.

\section{Process}

Social justice, transformation, and citizenship should define processes of engagement. By including perspectives of communities, we can create awareness and valorise the efforts of citizens to transform their environments. My position at UCT and my work in the community allowed us to connect research interests to real-life community. Studiolight played a facilitating role to start the process of connecting with the community. At the beginning of 2019, community facilitators were introduced to educators, students, and administrators through a semester-long design studio in Macassar to learn, through participatory action research methods, about the processes and forms of communication that could instil confidence in both the community and students. Over and above the spoken and written word, a number of other active techniques to present ideas were used as participatory research, for example, drawing and photography (Van der Riet, 2008: 551). A series of field trips with community groups introduced students to their new unknown teaching and learning environment.

When the first phase of the winter school started, the community was accustomed to visiting students and the processes of engagement, and the local students were familiar with the 
new learning environment and community. Student working groups were created with members from all universities. Groups teamed with members of the community. The groups could now take a deeper look at how the meeting of space and social relation allows for the emergence of situated knowledge.

\section{Mutually beneficial relationships}

Bhagwan delineates mutually beneficial relationships as establishing partnerships that support principles of reciprocity and a commitment to engage and learn together (2017: 179). To create a common interest, participatory methods were used to tie into the teaching and learning objectives. Methods such as street photography, recording oral histories, and mapping were employed as additional tools to conventional architectural drawing and modelling. Lectures and workshops were presented by members of the community and local experts in the built environment. Students developed architectural ethnographic drawings focusing not only on documenting the existing spatial situation, but also the techniques with which the spaces were constructed and used, as reflected in Figure 8.
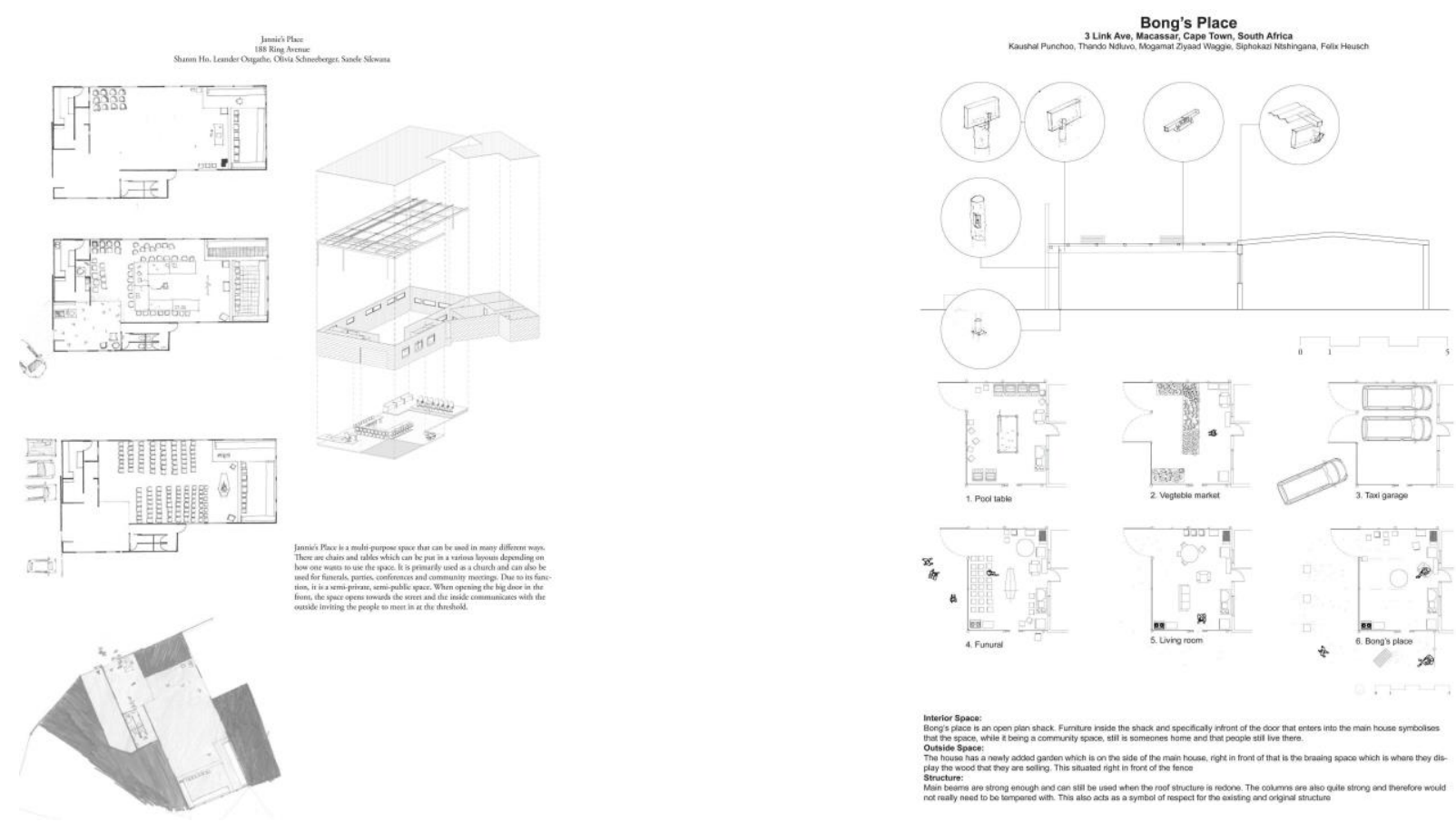

Figure 8: Architectural ethnographic drawings made by students to understand the tectonic ideas of a self-made space used during the first phase for workshops, lectures and exhibitions, as well as that of the shack in the second phase. Drawings by students.

Using these drawings students generated an urban-design framework that explored the codesign and collective making of a positive urban space. In parallel, four groups generated ideas for the roof design that could test local building knowledge at full scale. 
By the end of the first phase, a relationship of trust between the community and students was well established. Additional outside expert voices were not included as had been originally planned, as these could potentially silence the community voices and shift the focus. An exhibition was held in the community to solicit feedback (Figures 9 and 10). Students presented their findings and ideas. The community highlighted certain design concerns and made suggestions for improvement. One roof design was selected by the educators together with the shack owner. This design was developed by staff and students using online sharing platforms to produce technical documentation in preparation for the final build (Figure 11).

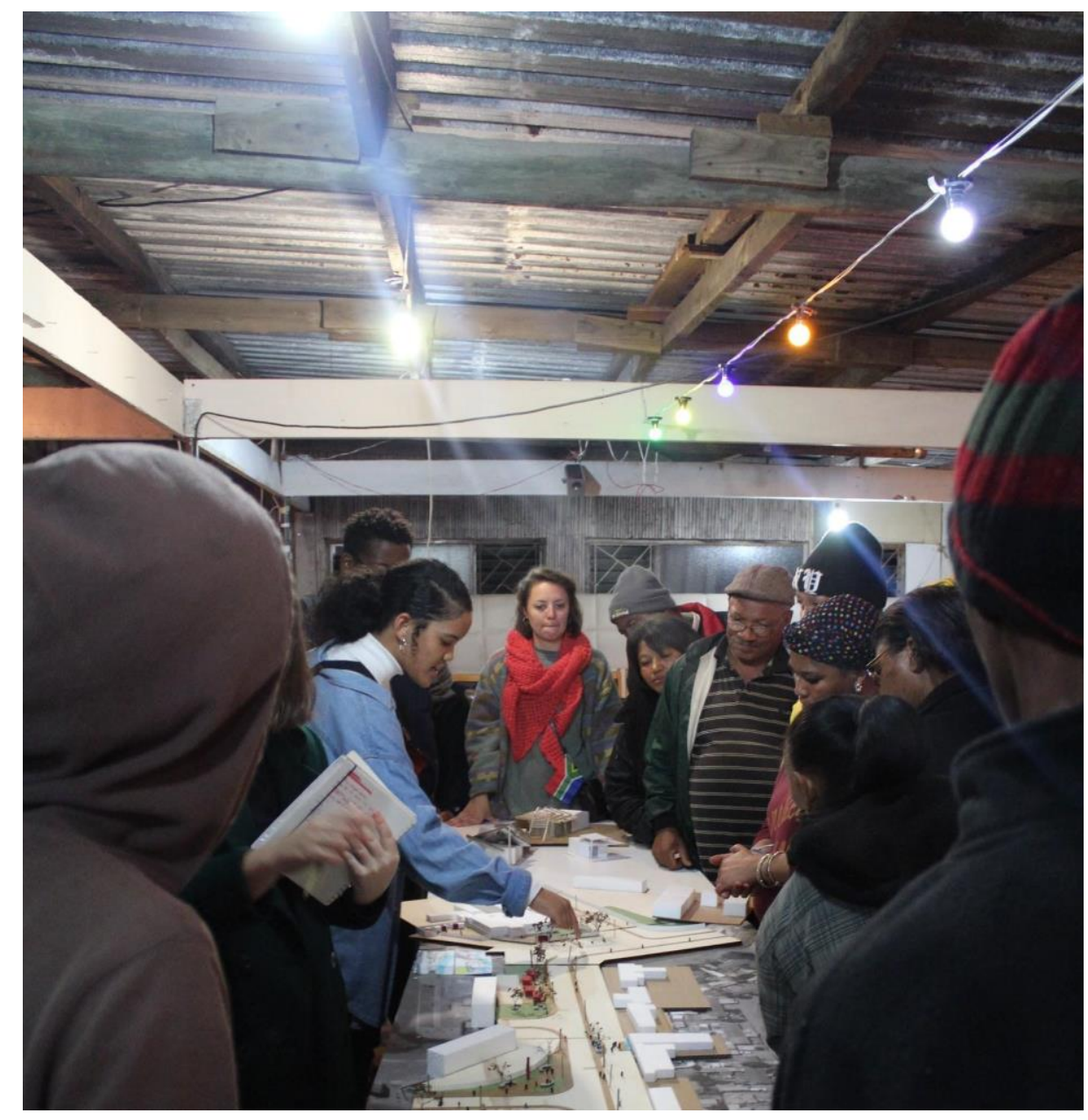

Figure 9: Students present the urban design to members of the community. Photograph by author. 


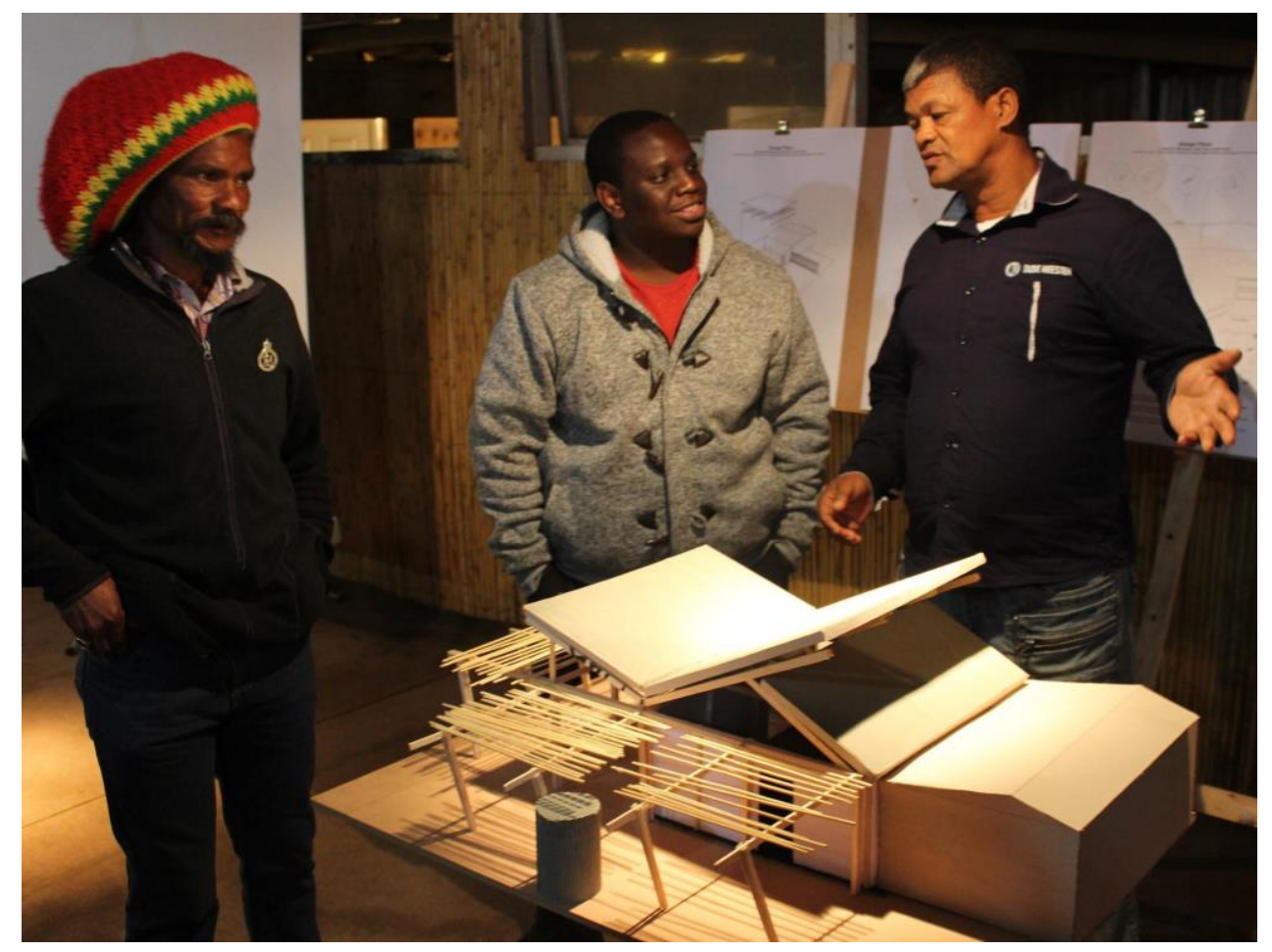

Figure 10: Students and community members discuss the roof design for the shack refurbishment in the second phase of the live project. Photograph by author.

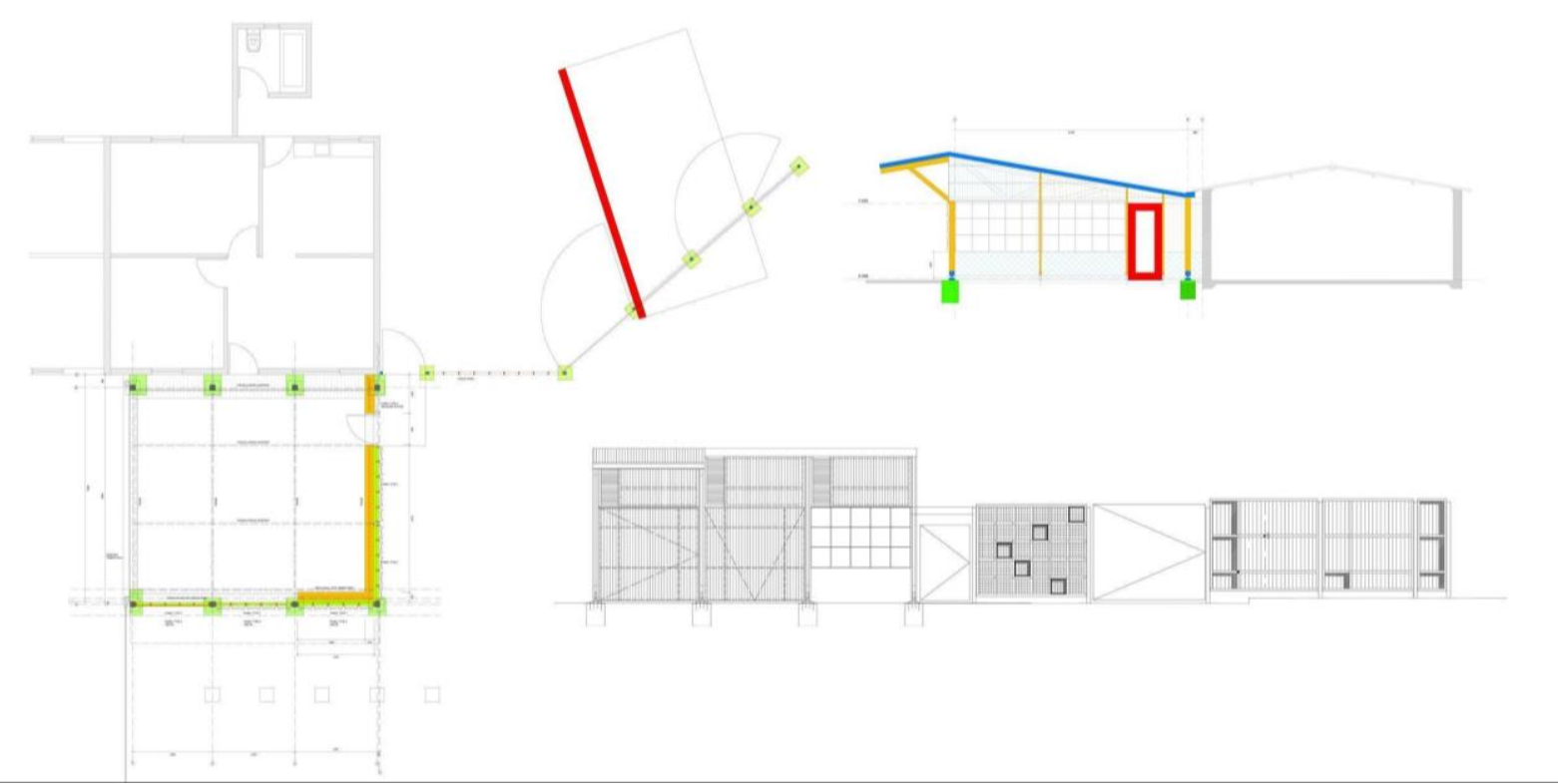

Figure 11: Final shack drawings for construction. Drawings by students. 


\section{Knowledge production}

Community engagement is about how we include non-experts and their experiential knowledge (Bhagwan, 2017: 179). Developing authentic engagement relies on recognising communities as co-producers of knowledge. In the second phase, careful planning created opportunities for the community to participate in the building process. Concrete works were scheduled before the arrival of the students, allowing the community to kick-start the process. The local secondary school offered their workshop for the testing and production of building components (Figure 12). This avoided any disruptions or concerns raised by policy land use ordinances. The idea was to create components out of sight and to erect these quickly - a subversive practice commonly associated with informal building practices and the spatial practice of Studiolight.

While students were making building components in the workshop, the community disassembled the old shack. The remaining masonry work on site was completed by the students under the supervision of community bricklayers, as seen in Figure 13. Metal work was completed by a local welder and brick paving by a local bricklayer. Students explored local building techniques using timber and other recycled materials to produce an environmentally responsible roof and wall system. Students designed and built robust and visible connections seen in Figure 14 and 15, which communicated the narrative of the construction process and assembly.

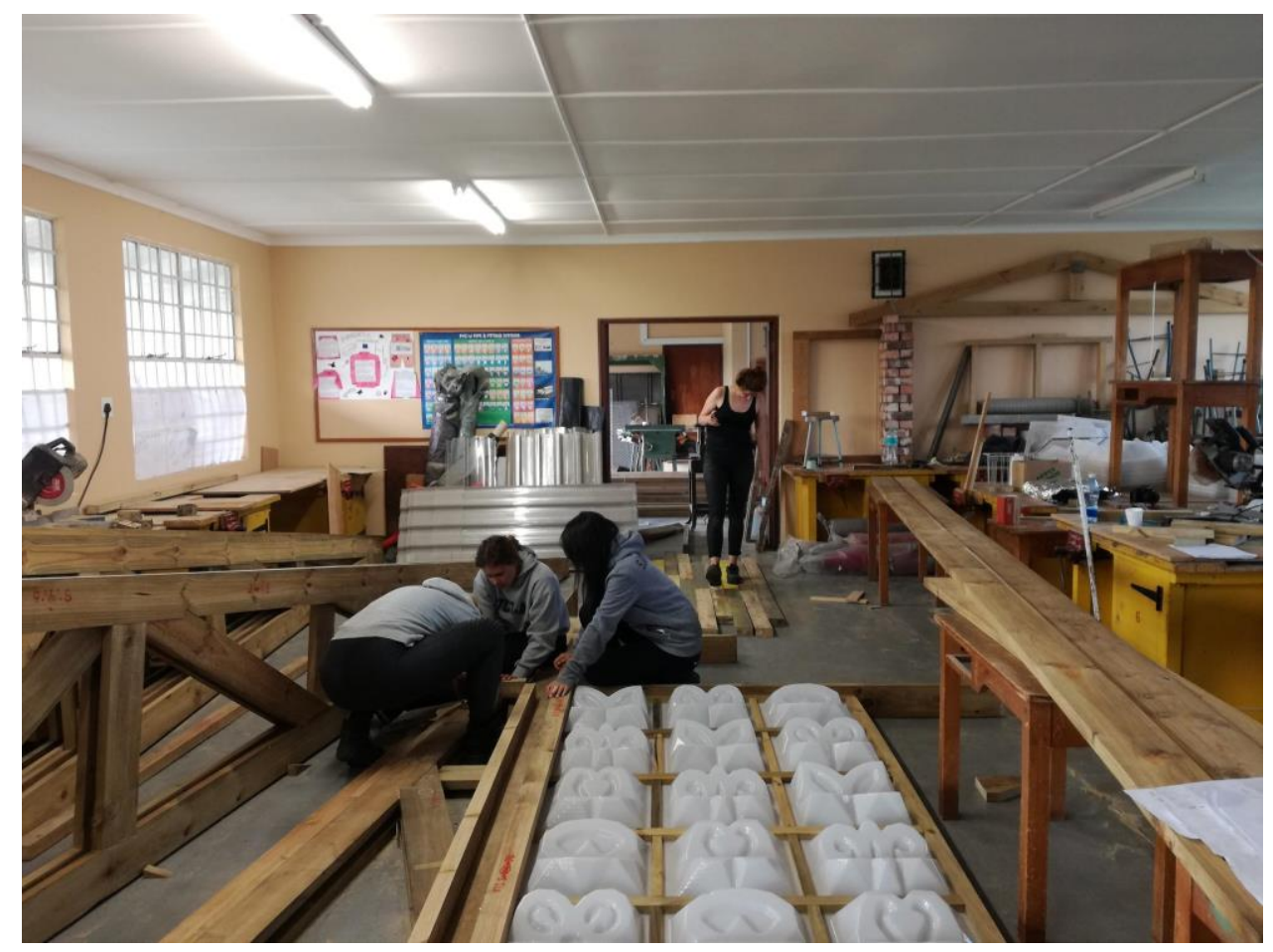

Figure 12: Students make building components in the nearby secondary school workshop.

Photograph by author. 


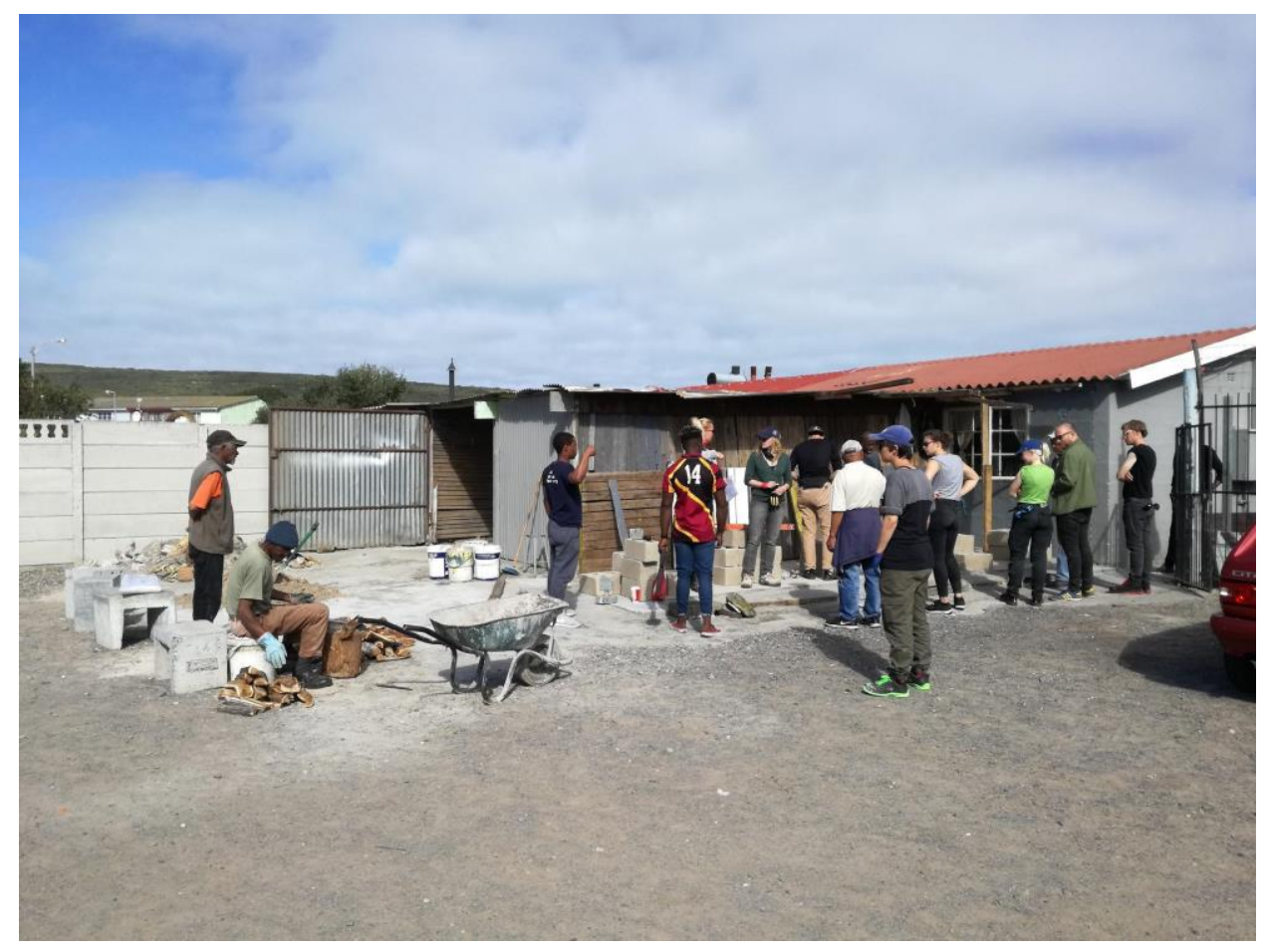

Figure 13: Masonry work completed by students and members of the community. Photograph by author.

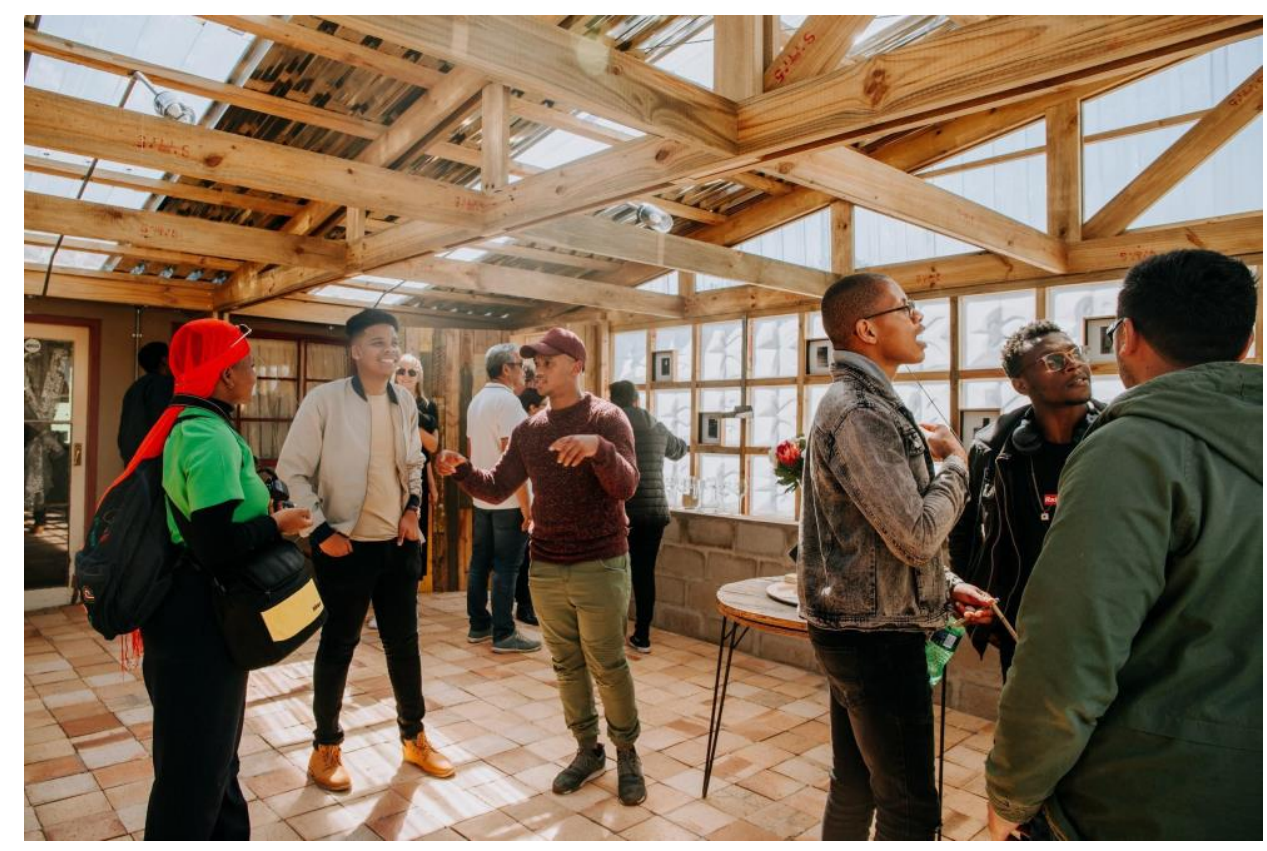

Figure 14: Interior view of the completed shack. Photograph by Candice Lowin. 


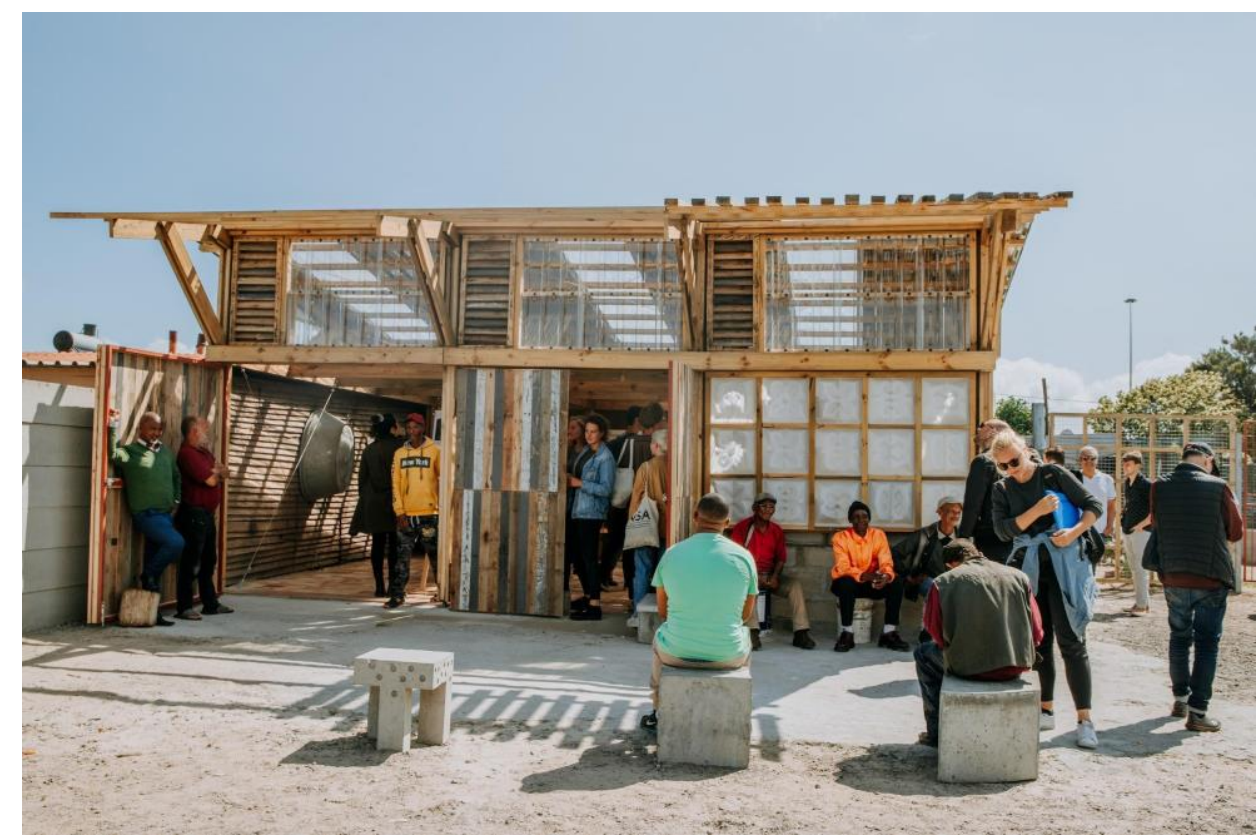

Figure 15: Exterior view of the completed shack, with positive outdoor space created towards the street. Photograph by Candice Lowin.

\section{Discussion}

Figure 16 summarises the Macassar project and aims to indicate the connectedness of the multiple overlapping contexts, the process, the relationships, and the subsequent knowledge (and in this case, the built structure) production as an interrelated result of the being-in-context of many stakeholders.

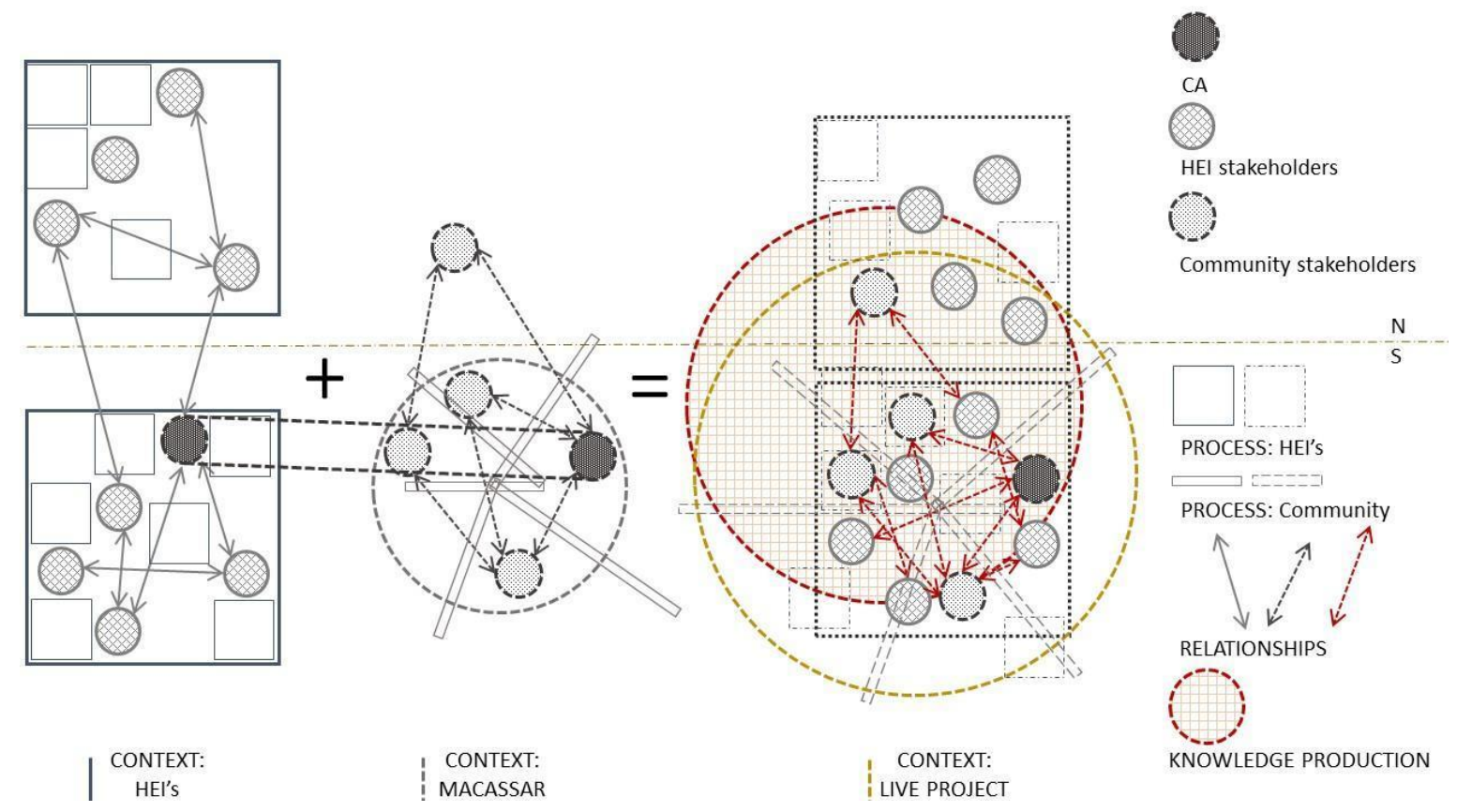

Figure 16: The Macassar live project context, process, relationships and knowledge production. Diagram by author. 


\section{Context}

The experience described in the narrative shows that being from a community does not make it any easier for an educator to initiate live projects in that community. On the contrary, a context like Macassar - where a history of oppression has instilled the notion that help can only come from the oppressor - can make it even more challenging. The saying that 'a prophet is not without honour except in his own country' (Luke 4:16-30 NIV) came to mind when describing the process of gaining community members' trust. The situated educator became familiar to the community through smaller social relief work projects (see Abrahams, C. In press). This convinced the community that he possessed the hard skills to effect concrete change. In the higher education institution context, being from a less fortunate community presented itself as an opportunity to solicit the interest from social-minded higher education institution participants. Many students appeared to demonstrate increased connection with the underlying authentic message advocated by the live project.

\section{Process}

Connecting with the community proved successful when the learning objectives of students were framed as part of existing ongoing community engagements. These learning objectives communicated that we were not only there to learn from the community but also to contribute to their ongoing causes. This connection signified the process towards the legitimising of the community's situated knowledge. Many students shared their appreciation for the community's time and willingness to participate in their learning. The students' response to what it meant to work with community members was often framed by a personal adoption of someone's story and a commitment to explore spatial conditions that can better support the daily activities of these stories. In the end, the student participants' willingness to improve themselves and the living conditions of others showed a commitment to social justice, transformation, and good citizenship. The value of a sustainable long-term process with a community was also foregrounded.

\section{Mutually beneficial relationships}

These partnerships prioritise new learning opportunities for students by engaging with previously unexplored areas. The challenge is to identify the benefits for a community that has little confidence in these processes because of previous exploitative experiences. Realistic, beneficial outcomes were set with a smaller group as representatives of a larger neighbourhood, and this allowed uncomplicated, effective feedback sessions. Foregrounding social impact as a meaningful outcome ensured that non-material outcomes were valued as much as material outcomes.

We argue that the live project is an inquiry into the creation of effective spaces for engagement, production, and implementation. Identifying and appropriating these opportunities required insight from the community and design thinking by the students. The identification and 
use of self-made spaces for exchanging ideas, redundant workshops for the production of building components, and the refurbishment of the shack as implementation all created opportunities to co-design solutions between students and the community.

\section{Knowledge production}

The live project in Macassar demonstrated how architectural knowledge is produced in the community's self-made spaces. This allowed students to develop their skills and created awareness in community members concerning their own efforts to improve their neighbourhood. The co-creation of knowledge is demonstrated in two ways. Firstly, through the making of architectural ethnographic drawings. Drawings, transcripts of interviews, and photography produced by students offered invaluable resources that built on the repository of stories collected. These valuable resources are often kept in academic spaces and not reintroduced back into the community. The situated educator's previous experience has shown that in community engagement projects it is often accepted that building the capacity of community is sufficient, and that through individuals, the knowledge will be disseminated back into the community. Other forms of knowledge and knowledge distribution should, however, be invested in - particularly in forms accessible to all.

Secondly, the completion of the shack is a tangible outcome that represents the coming together of community and student knowledge. A regular visitor, Boet Hendry, commented 'I never thought of using timber in this way ... this is giving me new ideas for adding onto my existing house'. After its completion, many other locals visiting the space are prompted to rethink how to improve their self-made spaces by learning from the shack's ways of making.

When discussing indigenous knowledge in the studio, vernacular architectures are often proposed by students. Many of these vernaculars are not currently - or have never been practised by locals. The use of architectural ethnographic drawings depicted situated knowledge as a story. Students could reconstruct everyday events with illustrations that allowed connections to be made between present conditions and possible futures (Kajima, et al., 2018). In many of these drawings, local building knowledge by members of the community is depicted as having to-make-do. An example of this is the sharing of expertise of building with found materials. Ideas generated from these drawings did not refer to architectural traditions that would be considered as vernacular architecture in the studio. In a way, students were able to recognise the voices of others as well as their own by embracing unpredictable scenarios rather than preconceived notions. It could be argued that, in this manner, students were able to reinterpret their architectural knowledge through the situated knowledge of the community.

\section{Conclusion}

In live projects in South Africa today the danger exists that members of an academic community enter into another community without fully hearing - let alone listening to - the voices of that community. This danger is all the more substantial in helicopter projects, where students from remote contexts enter communities that manifest complex social, economic, and political 
realities. It is essential that the voices of these communities are taken into account.

We have used the critically reflective narrative of a situated educator to consider just one live project in the community of Macassar. The situated educator had the unique vantage point of coming from both the academic community and the community in which the live project was set. Such a hybrid background would not automatically qualify a situated educator to become a leader or intermediary, nor provide the entitlement to represent the interests of the community. However, by introducing some of the participatory methodologies described in this paper, a situated educator could help to consider how the context of the university and the context of the community as two distinct but overlapping contexts allows us to define a new context in which all participants are comfortable enough to participate. We believe that having successfully engaged students from both global hemispheres in one project provided clues to how less desirable characteristics of helicopter projects can be mitigated.

This new context created by the overlapping of two very different contexts requires transparency with regard to anticipated outcomes: both learning outcomes for students and project outcomes for the community. Common objectives, mutual respect, and mutual trust in the other's ability to contribute are necessary to generate high energy levels to sustain a live project. Student enthusiasm and the community's renewed sense of trust must be valued and gradually nurtured. In the project narrative, the situated educator highlighted just how challenging it is to manage this convergence. Managing the trust and expectations of a community while instilling confidence in students to learn from an unfamiliar environment (rather than treating it as a venue for voluntary outreach) requires a deep understanding of both contexts. Having situated knowledge of both worlds and being perceived distinctly in both (architect to the community and community activist to the students), balancing cause and proficiency in architectural knowledge was important to not compromise the transfer of technical skills for students' learning.

We set out to define how pedagogies-in-context valorise the different knowledges that exist within a live project and allow for multiple ways of being-in-context - as students, educators, researchers, and community members. The discussions and conversations held during the project provide valuable insight into how students actualised this being-in-context and will be explored in further research. Many of the students described their experiences as unique and purposeful, with some identifying the educational experience as essential for developing the soft skills needed to work in the real world. The community members developed their being-in-context in different but no less important ways. Building people's capacity, developing ideas to better their places, capturing their lived experience as knowledge in ways that are meaningful and communicable and, of course, the refurbishment of an actual building that can be used by the community are all evidence that the community benefited. The relationship between students and community created in the live project helped to create meaningful places for underserved groups and neglected places while fostering responsible citizens at higher education institutions and in communities (Crisman, 2007: 143). 


\section{Acknowledgements}

Other educators who have contributed to the live project in Macassar include Bernadette Heiermann of RWTH Aachen University and Judith Reitz of PBSA Dusseldorf University, who were instrumental in securing funding from DAAD, as well as Thomas Schlaplik, Arne Künstler and Franz Klein-Wiele, who participated in the technical development of the design and the planning and execution of the building process. Carin Smuts of CS Studio Architects in Cape Town contributed her knowledge on community engagement to the live project, and impressed on the students how architecture can support social justice. Her collaboration with RWTH, PBSA and UCT on previous live projects, as well as with Clint Abrahams in her architectural practice, played a crucial role in bringing stakeholders together to develop the work that was initiated by the community.

\section{Author Biographies}

Clint Abrahams is an architect and lecturer at the School of Architecture, Planning \& Geomatics at the University of Cape Town, South Africa. His research in emergent architectural tectonic cultures critically engages postcolonial narratives in South Africa. In 2020 he was awarded UCT creative works award for his design-build exhibition 'Who we are Macassar'.

Hermie Delport is the head of the School of Architecture and Spatial Design at STADIO Higher Education. She has a keen interest in curriculum development, architectural education, community engagement and the sustainable, inclusive practice of live and design-build projects as alternatives to the traditional studio.

Rudolf Perold is a senior lecturer at the Cape Peninsula University of Technology. He coordinates the Advanced Diploma (Architectural Technology). He is a professional architect and urban geographer, holds a MA degree in Africa Studies ( University of the Free State) and a joint PhD in Architecture and Geography (Hasselt and Stellenbosch Universities).

Anna Marijke Weber is an architect living in Aachen, Germany. At Rheinisch-Westfälische Technische Hochschule Aachen University she heads projects combining research, teaching and student self-build formats focusing on typological aspects. She is partner in various research collaborations with national and international institutions. 2018 she received the North-RhineWestphalian award for young architects.

James Benedict Brown is an Associate Professor at Umeå School of Architecture, Umeå University, Sweden, with a particular interest in critical pedagogy and the role of design-build and live projects in architectural education. 


\section{References}

Abrahams, C. In press. Building community: Emergent common spaces. Architecture South Africa, 96: pp-pp.

Architekturmuseum der TUM. 2020. Experience in action! DesignBuild in architecture. Exhibition at Architekturmuseum der TUM, Munich, Germany. 19 May - 13 September 2020. Available at: https://www.architekturmuseum.de/en/exhibitions/experience-in-action/ (Accessed 8 June 2020).

Anderson, J. \& Priest, C. 2012. Developing a live projects network and flexible methodology for live projects. Paper presented at the Architecture Live Projects Pedagogy International Symposium, Oxford Brookes University, Oxford, United Kingdom. 24-26 May.

Anderson, J. \& Priest, C. 2014. Developing an inclusive definition, typological analysis and online resource for live projects. In Harriss, H. \& Widder, L. (eds.) Architecture Live Projects: Pedagogy into Practice. Abingdon: Routledge. 9-17.

Bender, G. 2008. Exploring conceptual models for community engagement at higher education institutions in South Africa. Perspectives in Education, 26(1): 81-95.

Bernardo, M.A.C., Butcher, J. \& Howard, P. 2014. The leadership of engagement between university and community: Conceptualizing leadership in community engagement in higher education. International Journal of Leadership in Education, 17(1): 103-122.

Bhagwan, R. 2017. Towards a conceptual understanding of community engagement in higher education in South Africa. Perspectives in Education, 35(1): 171-185.

Brown, J.B. 2012. A critique of the live project. Unpublished PhD diss., Queen's University Belfast, United Kingdom.

Brown, J.B. 2014. Learning theories for live projects. In Harriss, H. \& Widder, L. (eds.) Architecture Live Projects: Pedagogy into Practice. Abingdon: Routledge, 18-23.

Brown, J.B., Morrow, R. \& McAllister, K. 2012. Situated knowledges: Theorising the live project. Paper presented at the Architecture Live Projects Pedagogy International Symposium, Oxford Brookes University, Oxford, United Kingdom. 24-26 May.

Calleson, D.C., Jordan, C. \& Seifer, S.D. 2005. Community-engaged scholarship: Is faculty work in communities a true academic enterprise? Academic Medicine, 80(4): 317-321.

Chang, H., Ngunjiri, F. \& Hernandez, K.A.C., 2016. Collaborative Autoethnography. New York: Routledge.

Council for Higher Education (CHE). 2004. Criteria for Institutional Audits. Report, Higher Education Quality Committee, South Africa.

Crisman, P. 2007. Making connections: Environmental and social action through design. In Boza, L. \& Rinehart, M. (eds.). Assuming Responsibility. Washington: Catholic University of America. 139-144.

Crossman, P. \& Devisch, R. 2002. Endogenous knowledge in anthropological perspective. In C.A.O. Hoppers (ed.) Indigenous Knowledge and the Integration of Knowledge Systems: Towards a Philosophy of Articulation. Cape Town: New Africa Books, 96-127.

Delport, H. \& Perold, R. 2016. Exploring collaboration in architectural education: Towards design- 
build projects. Architecture South Africa, 77: 42-47.

Department of Education (DOE). 1997. Education White Paper 3: A Programme for the Transformation of Higher Education. Report, Department of Education, South Africa.

Devos, T., De Blust, S. \& Desmet, M. 2018. Valuating narrative accounts in participatory planning processes: A case of co-creative storytelling in Antwerp, Belgium. In Devisch, O., Huybrechts, L. \& De Ridder, R. (eds.). Participatory Design Theory: Using Technology and Social Media to Foster Civic Engagement. London: Routledge, 13-26.

Fourie, F. 2003. Beyond the ivory tower: Service-learning for sustainable community development. South African Journal of Higher Education, 17(1): 31-38.

Fourie, F. 2006. In pursuit of a South African scholarship of engagement. Paper presented at the CHE-HEQC/JET-CHESP Conference on Community Engagement in Higher Education, Cape Town, 3-5 September.

Freire, P. 1972. Pedagogy of the Oppressed. New York: Penguin Books.

Hall. M. 2010. Community engagement in South African higher education. In CHE Kagisano Series (ed.) Community Engagement in South African Higher Education. Auckland Park: Jacana Media, 1-52. Available at: https://issuu.com/jacanamedia/docs/kagisano (Accessed 18 May 2020).

Harriss, H. 2014. Architecture Live Projects acquiring and applying missing practice-ready skills. Unpublished PhD diss., Oxford Brookes University, United Kingdom.

Hill, J. 2005. Occupying Architecture: Between the Architect and the User. Abingdon: Routledge. Julie, H., Smith-Tolken, A., McMillan, J. \& Dippenaar, H. 2019. Engaged Teaching and Learning in Higher Education Institutions. Workshop invitation, UWC Faculty of Community and Health Sciences, Bellville, 28 October.

Kajima, M., Stalder, L. \& Iseki, Y. 2018. Architectural Ethnography - Japanese Pavilion Venice Biennale 2018. Tokyo: Toto.

Kliewer, B.W. 2013. Why the civic engagement movement cannot achieve democratic and justice aims. Michigan Journal of Community Service Learning, 19(2): 72-79.

Lau, U. \& Seedat, M. 2015. The community story, relationality and process: Bridging tools for researching local knowledge in a peri-urban township. Journal of Community \& Applied Social Psychology, 25: 369-383.

Lyons, A. \& Mcllrath, L. 2011. Survey of Civic Engagement Activities in Higher Education in Ireland. Galway: Campus Engage.

Luke 4:16-30. Holy Bible, New International Version.

Mitchell, M. \& Ugodo, M. 2003. A Review of Narrative Methodology. Report, DSTO Systems Sciences Laboratory, Australia.

Moore, T.L. 2014. Community-University Engagement: A Process for Building Democratic Communities. Report, ASHE Higher Education, John Wiley \& Sons.

Netshandama, V. \& Mahlomaholo, S. 2010. The role of community engagement in higher education: Focus on the discourse relating to knowledge development. In Basov, N., Simet, G. F., Van Andel, J., Mahlomaholo, S. \& Netshandama, V. (eds.) The Intellectual: A 
Phenomenon in Multidimensional Perspectives. Leiden: Brill, 109-117.

O'Brien, F. 2012. Constructing service learning in South Africa: Discourses of engagement. In Preece, J., Ntseane, P.G., Modise, O.M. \& Osborne, M. (eds.) Community Engagement in African Universities: Perspectives, Prospects and Challenges. Leicester: National Institute of Adult Continuing Education, 197-214.

Ogbu, L. 2013. Why I'm an Architect That Designs for Social Impact, Not Buildings. TEDxMidAtlantic, 25 October. Available at: https://www.youtube.com/watch?v=x0MnGZ1gB4k (Accessed 15 April 2020).

Pain, R. 2004. Social geography: Participatory research. Progress in Human Geography, 28(5): 652-663.

Sara, R. 2004. Between studio and street: The role of the live project in architectural education. Unpublished PhD diss., University of Sheffield, United Kingdom.

Sheffield School of Architecture. 2013. A Handbook for Live Projects. Sheffield: University of Sheffield. Available at: https://www.sheffield.ac.uk/polopoly_fs/1.304156!/file/Live_Projects_ Handbook_Med_Single.pdf (Accessed 29 April 2020).

Stonorov, T. (ed.) 2018. The Design-Build Studio: Crafting Meaningful Work in Architecture Education. New York: Routledge.

Van der Riet, M. 2008. Participatory research and the philosophy of social science. Qualitative Inquiry, 14(4): 546-565.

Weissmüller, L. 2020. Der Dicke Blaue. Sueddeutsche Online, 18 May. Available at: https://www.sueddeutsche.de/kultur/architektur-lehre-kolonialismus-der-dicke-blaue1.4911513 (Accessed 8 June 2020).

Witthaus, G., Rodriguez, B.P., Guardia, L. \& Campillo, C.G. 2019. Next Generation Pedagogy: IDEAS for Online and Blended Higher Education. Report, FUTURA Project, Universitat Oberta de Catalunya. Available at: https://hdl.handle.net/2134/23893 (Accessed 26 May 2020). 